\title{
Research on Situation of Non-Regular Employees in Korea and Bill No. 1902259
}

\author{
Eric Beomjoon Kim
}

\begin{abstract}
Who are non-regular workers? As implied, the term non-regular workers refers to employees whose form of employment is not regular. Non-regular workers include temporary workers, part-time workers and other employees who have special forms of employment such as dispatched workers, employees of service companies and domestic workers. $17.3 \%$, which is only a small portion of the whole non-regular working population are specialized engineers and managers who are treated properly. On the other hand, other non-regular workers face various forms of discrimination within the workplace. This research provides for the elements that caused current situation of non-regular employees in Korea and how the Korean government is trying to handle the problem regarding temporary workers in schools and educational institutions, especially Bill No. 1902259 and its bright sides and potentially negative impacts.
\end{abstract}

Index Terms-Non-regular workers, non-regular employees, labor, education, school, government policy, bill No. 1902259

\section{INTRODUCTION}

As the Korean economy grew rapidly, the proportion of non-regular employees had been increasing up to the point that it is nearly impossible to expand anymore. Furthermore, Korean non-regular employement is different from that in other countries because of several reasons including the purpose of employing them and their treatment. This research tries to explain why current and past government actions were not effective and recommands which measures should be taken in order to fix the recently proposed bill, Bill No. 1902259.

\section{Situation In Korea AND the CAUSE}

Based on statistics (See Fig. 1) collected in 2012 [1], there are currently 5,911,000 non-regular workers in Korea. This means that out of the entire working population of $17,734,000$, approximately 33.3 percent may be exploited for their labor or have been treated unfairly. Ever since South Korea overcame IMF financial crisis that struck in the 1990s, the country expanded its economy rapidly. As the economy grew, its non-regular working population increased as well and the increase continued until August of 2008. Since August 2008, the percentage of the non-regular working population has stayed between $33 \%$ and $34 \%$. This phenomenon indicates that society has expanded the population uncontrollably up to the point it cannot handle and

Manuscript received September 7, 2013; revised November 23, 2013.

Eric Beomjoon Kim is with the Hanyoung Foreign Language High School, Republic of Korea (e-mail: shateie195@gmail.com). finally it is making and showing some progress on regulating non-regular employment.

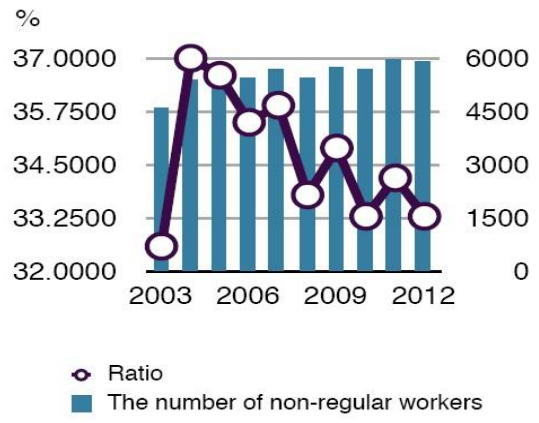

Fig. 1. Size of non-regular working population (From Korea National Statistical Office).

Why is non-regular employment brutal? The problem in this form of employment is that even though there exists no difference between the work of a regular worker and that of a non-regular worker, the latter is discriminated. There are three categories of unfair treatment received by non-regular workers: discrimination in pay, working environment and employment instability. According to the statistics released by the Ministry of Employment and Labor [2], the gap between total wage of regular worker and that of a non-regular worker in a same company is 9.1 percent and the gap of hourly wage was 4.2 percent. The discrimination in working environment is evident in the gap between social insurance coverage rates and in the gap between the working welfare benefit rates. Table $\mathrm{I}$ is about working welfare benefit rates from statistics collected by Korea National Statistical Office [3].

TABLE I: WORKING WELFARE BENEFIT RATE (FROM KOREA NATIONAL STATISTICAL OFFICE)

\begin{tabular}{|l|c|c|c|c|c|c|c|c|}
\hline & \multicolumn{4}{|c|}{2011.8} & \multicolumn{3}{c|}{2012.8} \\
\hline & $\begin{array}{l}\text { Severance } \\
\text { pay }\end{array}$ & $\begin{array}{l}\text { Bonus } \\
\text { pay }\end{array}$ & $\begin{array}{l}\text { Overtime } \\
\text { pay }\end{array}$ & $\begin{array}{l}\text { Paid } \\
\text { Holiday }\end{array}$ & $\begin{array}{l}\text { Severance } \\
\text { pay }\end{array}$ & $\begin{array}{l}\text { Bonus } \\
\text { pay }\end{array}$ & $\begin{array}{l}\text { Overtime } \\
\text { pay }\end{array}$ & $\begin{array}{l}\text { Paid } \\
\text { Holiday }\end{array}$ \\
\hline $\begin{array}{l}\text { Paid } \\
\text { workers }\end{array}$ & $64.7 \%$ & $65 \%$ & $43.7 \%$ & $56 \%$ & $66.7 \%$ & $66.6 \%$ & $45.2 \%$ & $58 \%$ \\
\hline Regular & $78.4 \%$ & $80.4 \%$ & $55 \%$ & $69.2 \%$ & $80.2 \%$ & $81.8 \%$ & $56.2 \%$ & $71 \%$ \\
\hline $\begin{array}{l}\text { Non- } \\
\text { regular }\end{array}$ & $38.4 \%$ & $35.5 \%$ & $22 \%$ & $30.5 \%$ & $39.6 \%$ & $36.4 \%$ & $23.2 \%$ & $32.1 \%$ \\
\hline
\end{tabular}

Korea's Welfare benefit rate is in increasing trend. However, in terms of severance pay, bonus pay, overtime pay, and paid holidays, the proportion of non-regular workers out of total non-regular workers being properly treated out of total non-regular workers is significantly low compared to the proportion of regular workers. The gaps between rates of national pension insurance registration, national health insurance registration and national employment insurance 
registration are $40.9 \%, 36.8 \%$ and $35.1 \%$, respectively. Lastly, in terms of employment instability, it turned out that regular workers were hired for 6 years and 10 months in average whereas non-regulars were hired for 2 years and 4 months in average, making the former group's period approximately three times longer than the latter. This proves that non-regular workers face significantly unfair treatment from their employers compared to the treatment of regular workers.

Why are these people discriminated? Though, it is hard to compare the situations of two very different countries since forms of employment are different, comparing Korea and France tells us something about the answer. According to the 2008 OECD Employment Outlook, the non-regular working proportion is 29.7 percent, placing Korea in the second place on the list of the World's biggest non-regular ratio. On the other hand, the proportion for France is $12.3 \%$, which is less than half of Korea's. What is important to focus on is not the numbers, however. It is the definition and treatment of French non-regular workers.

From the beginning, non-regular employment in Korea and France can't be the same in definition because they differ in the background they were created. According to Jun [4], France created the concept of non-regular employment in order to solve the unemployment problem and it is keeping its position of allowing the form of employment only when it is used to supplement the regular workers in contrast to Korea, where non-regulars are used to replace regular workers. France has been sticking to the idea of prohibition in principle and permission only in exceptions. It is pretty obvious that the transition rate from non-regular to regular workers is much higher in France than in Korea and the treatment is significantly better in France. According to a published study [5], French Labor Law (Code Du Travail) states that a regular employment contract is the principle form of employment and non-regular employment is only allowed in special situations for a given period of time. Therefore, it is illegal to continuously replace or employ non-regular workers for full-time jobs in France. The government effectively regulates non-regular employment by limiting both its purpose and period. The French Legal Code reflects the philosophy stating that non-regulars should not be used to cut down labor cost. This is why France is not experiencing the same social conflict that Korea is, even though France is changing toward a dual economy just like Korea.

To the contrary, in 1990s when the economy was booming, Korean companies sought to hire cheap labor with minimum cost possible. Non-regular workers were immensely hired and treated unequally. This means that non-regulars were employed to replace regular workers rather than to supplement regulars. Consequently, it is somewhat obvious that the transition rate of non-regular to regular worker is really low.

\section{Non-Regular Workers in the Field of Education}

Based on some statistical data [6], out of 350,000 public non-regular workers, education institutions (schools and academies) take the largest proportion with approximately
150,000 non-regular employees. Classifying by specific occupations, workers related to school meal system (ie: school dietitian and cook) take the lead with 43 percent $(65,214)$ and other occupations such as school assistants $(13140,9 \%)$ and childcare assistants $(6245,4 \%)$ follow the lead. Just like in other fields, non-regular workers in the education industry suffer from low pay and less social benefits (see Table II).

TABLE II: SALARY GAP BETWEEN DIETARY TEACHER AND DIETITIAN (FROM NATIONAL ASSEMBLY LIBRARY)

\begin{tabular}{|c|c|c|c|c|c|c|}
\hline \multirow{2}{*}{} & \multicolumn{2}{|c|}{$\begin{array}{c}\text { Worked for 1 } \\
\text { year }\end{array}$} & \multicolumn{2}{c|}{$\begin{array}{c}\text { Worked for 5 } \\
\text { years }\end{array}$} & \multicolumn{2}{c|}{$\begin{array}{c}\text { Worked for 10 } \\
\text { years }\end{array}$} \\
\cline { 2 - 7 } & $\begin{array}{c}\text { Annual } \\
\text { Salary }\end{array}$ & $\begin{array}{r}\text { Ratio to } \\
\text { regular }\end{array}$ & $\begin{array}{c}\text { Annual } \\
\text { Salary }\end{array}$ & $\begin{array}{c}\text { Ratio to } \\
\text { regular }\end{array}$ & $\begin{array}{c}\text { Annual } \\
\text { Salary }\end{array}$ & $\begin{array}{c}\text { Ratio to } \\
\text { regular }\end{array}$ \\
\hline $\begin{array}{c}\text { Dietary } \\
\text { teacher } \\
\text { (Regular) }\end{array}$ & $\begin{array}{c}30,185, \\
258\end{array}$ & $100 \%$ & $\begin{array}{c}33,107, \\
642\end{array}$ & $100 \%$ & $\begin{array}{c}40,161, \\
995\end{array}$ & $100 \%$ \\
\hline $\begin{array}{c}\text { Dietitian } \\
\text { (Non-regular) }\end{array}$ & 18,571, & $62 \%$ & 18,571, & $56 \%$ & 18,571, & $46 \%$ \\
\hline
\end{tabular}

Non-regular employees working in the education industry are paid around 1,000,000 won per month and it is $62 \%$ of a regular employee who is working for the first year [6]. The gap increases as work experience increases and finally, for those who have been working for the industry for 10 years, pay of a non-regular employee is only $46 \%$ of what a regular worker is paid. Compared to the situation of regular employees in which a pay step system exists and pay is proportional to work experience, there is no such system that exists for non-regular employees. Two things that an interviewee who is a dietitian with a non-regular contract said were: the harshest among numerous discrimination to non-regulars, one is the pay system that does not reflect work experience. She said that notwithstanding the fact that the gap is already big from the first year pay, it is even harder to admit that the gap increases as she keeps working for her school.

Besides pay, other forms of discrimination exist. Another one is the instability of employment. Unlike the regular employees, who are employed by superintendents of schools, non-regular workers are employed by school principals or chairmen of schools' foundations. This means that non-regular employees in school are subject to instability that is virtually the same as that caused by the restructuring of a company and there is threat of arbitrary dismissal. The dietitian interviewee also said that the second form of discrimination that she feels hard to accept is the instability of employment and added that not only is it unreasonable but also is diminishing her work efficiency because she is constantly in danger of being jobless.

Furthermore, the interviewee said unlike the past, married women have to work to help support their families, but since they are the ones who are having babies and raising them, they cannot work continuously for a long period. Working temporarily is not their fault. However, because of their situation, they are discriminated in workplace even though they are as competent. 


\section{ANALYSIS OF GOVERNMENT ACTION}

\section{A. Necessity of Government Action}

The reason why there has to be new government action regarding non-regular employees in the education industry is not just because of the various forms of discrimination. According to a statistics from National Archive [6], as the demand for teachers and teaching assistants rose steeply, the number of workers who are not proper government employees increased. In 2012, the number increased by $17 \%$ $(22,153)$ compared to that of the previous year. At this point, it is reasonable to say that the current situation is not well reflected by the Korean labor law because the labor law, originally intended to apply to companies seeking profit, is not suitable to apply to the educational field considering its unique circumstances and characteristics. In addition, since problems of employment, management, improvement of conditions, and more are being handled by individual provincial governments, it leads to inequity among jurisdictions and conflicts among labor unions, thus leading to the conclusion that there is a need for one integrated labor law for just the education industry.

\section{B. Overview of Bill No. 1902259}

Proposed by the Democratic United Party in 2012 National Assembly, Bill 1902259 creates a new system of employment or an office called educational civil servant, employes current workers who are neither teaching staff nor government employed administrative staff classified by Elementary and Secondary Education Law, and give the same treatment as that provided to original regular employees. It is predicted that this new law will improve the current conditions of non-regular employees in schools.

This bill will be effective in dealing with various discriminations of pay. It is declared by presidential decree to give equal annual pay to the newly created educational civil servants. Along with annual pay, the bill improves non-duty allowance for previous non-regulars as well. For example, during school breaks, educational civil servants will be paid seventy percent of their original pay. Furthermore, in contrast to the wage system of previous non-regular staff, a pay step system in which work experience is proportional to a staff's pay is introduced to educational civil servants as well. In terms of other special allowances or benefits such as family allowance and child tuition aid benefits, they are given as well to previous non-regular employees from now on once the bill passes.

This bill is also very effective in handling the issue of employment instability. The bill restricts employers of educational civil servants from setting specific periods of employment. Except for the case when there is a legitimate excuse for dismissal, employees are guaranteed with employment until retirement age. In special cases in which the need for temporary employment is acknowledged, the employer can have a temporary contract with someone for a maximum of one year. If the worker continues working after one year has passed, the worker is automatically converted to an educational civil servant.

Educational civil servants in national schools and Ministry of Education affiliated institutions will be employed by the minister of Ministry of Education, educational civil servants in public schools, affiliated kindergartens and municipal government offices will be employed by the superintendent of education, and educational civil servants in private schools will be employed by administrators of the schools.

Lastly, it is effective in terms improving working environment. This is because the $6^{\text {th }}$ section of the bill specifically provides for protection of educational civil servants' work hours, holidays, breaks, etc. Unless prohibited by other labor related laws, Bill 1902259 guarantees the rights of school administrative staff as set by Public Officials Service Regulation to educational civil servants. In other words, educational civil servants are protected to have the same rights as government employees. Furthermore, the bill gives the opportunity of various trainings for educational civil servants which were formerly not given to non-regular employees.

This bill, however, has three critical downsides.

The first is the possibility of a patronage system. As mentioned previously, according to types of schools and institutions, who employs educational civil servants is set by the bill and this section of the bill enables the employers (ie. minister of Ministry of Education and superintendent of education) to abuse their power to employ specific people who are not qualified but liked by the people who employ educational civil servants. If this actually happens, it means that the exact opposite of one of the purposes of the bill which is "to improve the quality of school education". Once it is made a law, it will be very hard to amend it. Therefore, this section of the bill has to be fully analyzed and consider the possibility of power abuse.

The second is the concern over emergence of a new privileged class. The effect of this bill is to create a new office of educational civil servants and to treat them similarly as government employees. This means that the formerly non-regular employees will keep their rights that are only entitled to laborers (ie. right to strike) by labor law and be treated as government employees who have other responsibilities. If this takes place, this will cause another type of discrimination. It is ironic that a law made to prevent discrimination against a group actually discriminates against another group.

The third and the most controversial one is the inequality in the opportunity to the public office and reverse discrimination. In order to impartially hire competitive government officials, Korea has practiced civil service examination system. It is a principle to pass the examination system if someone wants to become a government employee. However, this bill proposes to hire current unqualified non-regular workers as para-government employees and give them the same benefits that original government employees received. This is not only unreasonable but also causes reverse discrimination against students who have been preparing for the civil service exams for years.

The interviewee answered that while she agrees with the positive effects of the bill, it is not just that a law created to eliminate discrimination creates another form of discrimination and the bill should not be made a law on current terms. She also personally believed that it is better to improve the current labor law and its enforcement than to 
create a wholly different law.

\section{CONCLUSION}

It is not hard to reach a conclusion since it is clear what is causing the controversy. The first problem of the bill that was proposed in this research was the possible introduction of patronage system. This problem can be solved by qualifying the pool for transition since it is reasonable to believe that people that will take the office by using their acquaintances' power and influence are the ones who cannot become qualified on their own. In addition, some kind of qualification such as examination or work evaluation on current non-regular employees who are subject to transition is needed in order to eliminate discrimination against others who prepare for the civil service examination to become government employees. Lastly, to address the problem of the possibility of a new privileged class, the new government employees have to only have the rights as government employees not as private laborers. By this clear classification as government employees, they will not be a privileged working class.

\section{REFERENCE}

[1] S. H. Song and Y. A. Park, August-Statistics on Economic Population: Secondary Research on Non-Payed Labor Categorized by Types of Employment, Korea National Statistical Office, 2012.

[2] H. J. Ha, J. H. Kwon, and S.-P. Yang, Analysis of the Gap between Salaries of Regular and Non-Regular Workers, Ministry of Employment and Labor, 2011.

[3] Unknown, 2011 Research on Labor Situation Categorized By Types of Employment, Ministry of Employment and Labor.

[4] B.-Y. Jun, "Issue and alternative of non-regular employment," Korea National Strategy Institute Analysis No. 146, Korea National Strategy Institute, 2009.

[5] S. C. Chang, "French non-regular employment," International Labor Brief 2009 May Issue, Korea Labor Institute, pp. 15-27, 2009.

[6] Various (Initiator: Congressman Yoo Ki-Hong, Congressman Jung Jin-Hoo), Policy Debate about Regularization of School Non-Regular Employees, National Assembly Library, 2012.

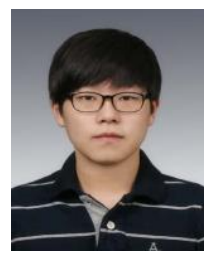

Eric Beomjoon Kim is from Hanyoung Foreign Language High School in South Korea. Kim was born in Texas, U.S. Kim is primarily interested in studying economics and labor studies. 